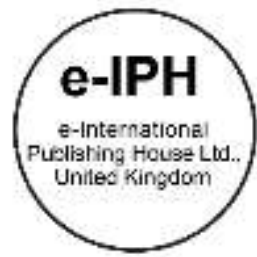

\title{
Linear Street Pattern in Urban Cities in Malaysia Influence Snatch Theft Crime Activities
}

\author{
Siti Rasidah Md Sakip ${ }^{1}$, Mohd Najib Moihd Salleh² \\ 1 Department of Landscape Architecture, Faculty of Architecturre, Planning \& Surveying \\ Universiti Teknologi MARA Perak Branch Seri Iskandar Campuis, Malaysia \\ 2 School of Housing, Building \& Planning, \\ Universitu Sains Malaysia, Penang Malaysia \\ sitir704@perak.uitm.edu.my, najibms@usm.my \\ Tel: 019-2798594:
}

\begin{abstract}
Malaysia is one of the countries that is having rapid urbanization and the crime rates are getting worried by the Malaysian government. Thus, this paper objective is to identify the street pattern characteristics that influence the snatch theft activities. The character of the street pattern is identified by using the GIS to construct, determine and analyse the area with high reported snatch theft cases. The result shows the area with the high number of snatch incidents is becoming a snatch theft hotspot area and the fragmented parallel type of street pattern influenced the snatch activities.
\end{abstract}

Keywords: CPTED, crime, hotspot, snatch theft, street pattern

eISSN: 2398-4287 @ 2018. The Authors. Published for AMER ABRA cE-Bs by e-International Publishing House, Ltd., UK. This is an open access article under the CC BYNC-ND license (http://creativecommons.org/licenses/by-nc-nd/4.0/). Peer-review under responsibility of AMER (Association of Malaysian Environment-Behaviour Researchers), ABRA (Association of Behavioural Researchers on Asians) and cE-Bs (Centre for Environment-Behaviour Studies), Faculty of Architecture, Planning \& Surveying, Universiti Teknologi MARA, Malaysia.

DOI: https://doi.org/10.21834/e-bpj.v3i8.1386

\subsection{Introduction}

Crime frequently happen in the urban areas because of its physical setting and the users' behavior (Block \& Block, 1995) which could present the crime activities. This shows that the opportunities to commit crime are possible since urban and crime are associated with each other. Besides that, the population in urban area is higher as compared to the population in the sub-urban areas (Levitt, 1999) which can also contribute to the number of crimes to occur especially when the living cost is high and lack of job opportunities in a city. Cozens (2008) stated that every potential threat to the long term health, endurance, personal safety and security of both built environment and its citizens must be considered in order to develop a sustainable city (Cozens, 2008) which is actually related closely with their needs in order to survive in the cities.

Snatch theft events are being in a worrisome level since some of this crime occurrence caused fatalities (Yew, 2012). This complication has been giving the societies and creates a huge impact on sense of panic, anxiety and fear which imperil the safety of the people. There are snatch theft incidents in Malaysia that has been announced in the local television news and when some video recordings that are being uploaded in the social media websites by witnesses went viral all over the nation. These incidents developed sense of fear among the urban citizens especially people who are walking to and fro a particular place (Lakshiny, 2016). The crime presence within an urban area are making the people's quality of life are getting deteriorated day by day. This statement also is supported by Colquhoun (2004) where it is important to get the design of the built environment right since good environment design has an essential conduct on the quality of life of the people.

eISSN: 2398-4287 @ 2018. The Authors. Published for AMER ABRA cE-Bs by e-International Publishing House, Ltd., UK. This is an open access article under the CC BYNC-ND license (http://creativecommons.org/licenses/by-nc-nd/4.0/). Peer-review under responsibility of AMER (Association of Malaysian Environment-Behaviour Researchers), ABRA (Association of Behavioural Researchers on Asians) and cE-Bs (Centre for Environment-Behaviour Studies), Faculty of Architecture, Planning \& Surveying, Universiti Teknologi MARA, Malaysia.

DOI: https://doi.org/10.21834/e-bpj.v3i8.1386 
Until today, Malaysia is facing difficulties on snatch theft issues. Malaysia is one of the countries that is having rapid urbanization and the crime rates are getting worst as well which become one of the threats that need to be faced by the citizens. The numbers of cases and incidents of snatch theft in Malaysia are fluctuating in the time-framed of 6 years which is from the year of 2010 until the year of 2015. Even though the figures in the statistical data of the snatch theft cases are fluctuating every year, the public's fear are still increasing year by year as stated by Tan Sri Lam Thye the Malaysia Crime Prevention Foundation (MCPF) vice chairman in the local newspaper (The Star, 2016). The conditions of snatch theft cases in 4 states in Malaysia is explained in the Table 1. There are four major cities within these states with high figures of reported cases of snatch theft which are in Selangor, Kuala Lumpur, Penang and Johor with 5,553 cases, 4,687 cases, 1,953 cases, and 298 cases respectively (PDRM, 2016a). In present days, cities are becoming more appealing towards the people particularly from rural areas due to its economic and employment opportunities to earn a living. Hence, the crime prevention and common crimes of opportunities such as snatch incidents should be address and target in an urban planning.

Table 1. Snatch Theft Crime Data of Four Major Cities in Malaysia from 2010 to 2015

\begin{tabular}{c|c|c|c|c|c|c|c}
\hline State & 2010 & 2011 & 2012 & 2013 & 2014 & 2015 & $\begin{array}{c}\text { Total by } \\
\text { State }\end{array}$ \\
\hline Selangor & 1247 & 799 & 726 & $\mathbf{9 8 5}$ & $\mathbf{8 4 6}$ & $\mathbf{9 5 0}$ & $\mathbf{5 5 5 3}$ \\
\hline Kuala Lumpur & 1901 & 951 & 385 & 214 & 632 & 604 & 4687 \\
\hline Penang & 835 & 197 & 280 & 165 & 245 & 231 & 1953 \\
\hline Johor & 84 & 76 & 38 & 28 & 39 & 33 & 298 \\
\hline \multicolumn{7}{c}{ (Source: PDRM, 2016) } \\
\hline
\end{tabular}

The government are conscious with this issue and is putting great exertion to reduce the crime rates through the Nation al Key Result Areas (NKRA) which has been established in the Government Transformation Program (GTP) in the year of 2004 (Jabatan Penerangan Malaysia, 2009). The Prime Minister has announced NKRA in July 2009 where one of the criteria includes the efforts in reducing crime. Other government-related agencies such as Home Affairs Ministry and Royal Malaysia Police (RMP) also are targeting the crime reduction as their top priority matters, which is through Crime Prevention through Environment Design (CPTED). This seems that CPTED and its awareness amongst the professionals of built environment has been taken into consideration since this matter is very important in order to reduce the crime rates especially in the urban areas because it can influence the residents' impression on safety and fear towards crime. CPTED is argued as a planning device that is favorable for assisting in the creation of more competent, sustainable and livable urban design (Cozens, 2008). It is becoming increasingly more critical for getting the building designs and the environment right, as the interest in CPTED is growing (Colquhoun, 2004). The existence of crime within an urban area are making the citizens' quality of life deteriorated. CPTED in Malaysia is known as the Safe City Program as a tool and guideline to reduce crime thus improving the citizens' quality of life. Therefore, it is essential especially for the architects, planners and other related fields involved to understand the importance of addressing the issu es (Colquhoun, 2004).

Therefore, this paper purposes is to find out what types of street pattern in urban area that affect the snatch theft activities recorded in the period of 6 years by using the Geographic Information System (GIS) to construct, determine and analyze the hot spot area of the snatch theft cases according to the data that has been obtained from the Royal Malaysia Police (RMP).

\subsection{Literature review}

\subsubsection{Crime Mapping and Hot Spots}

Geographic Information System (GIS) is a computer generated map which uses geography as an interface for merging and accessing large amounts of information based on location (Johnson, 2000; Weisburd \& McEwen, 1998). GIS is making the police personnel to be able to plan effectively for emergency response, distinguishing the reduction priorities, analyze historical events, and predict future events (Chainey, Tompson, \& Uhlig, 2008; Johnson, 2000). GIS plays an important role in crime mapping and analysis since it offers visual representations of crime-related issues of where and why crimes occur can improve attempts to fight crime (Johnson, 2000; Weisburd \& McEwen, 1998). GIS software helps integrate large amounts of multiple source location-based data where it allows the user to layer the data and view the data most critical to the specific problem (Johnson, 2000). It is used widely by both large and small police organization to provide mapping solutions for crime analysis, criminal tracking, traffic safety, community policing, and other various tasks (Johnson, 2000). In addition, GIS also could be used to explore the relationship between the environment and crime because mapping crime are able to help the police protect citizens more effectively and Policy makers in police departments might use more complex maps to look at the trends in criminal activity in solving criminal cases (Johnson, 2000; J. H. Ratcliffe, 2002; Weisburd \& McEwen, 1998). Anyhow, crime mapping has revived interest and reshaped many criminologists appreciation for the importance of local geography as 
a determinant of crime that may be as important as criminal motivation (J. Ratcliffe, 2011). A previous study was conducted by Ludin, Aziz, Yusoff, \& Razak (2013) in an area where it explains the spatial relationship of drug abuse and other criminal activities on urban land use planning and their implications on the society. The study was using spatial statistics to show patterns, trends and spatial relationships of crimes and land use planning. The data obtained together with digital land use maps produced are analyzed and the results showed the distribution of crime incidents and drug abuse in the area.

Crime that are likely to be undistributed over space and highly concentrated in some or certain areas and consists of fear concentration, no matter whether criminal incidents have occurred or not are called 'hot spots' (Wang et al., 2013; Cohen \& Felson, 2016b). 'Hot spots' of crime arise at a variety of scales from the community to the block to the specific situations (Sherman et. al., 1989; Maltz et al., 1990). After a crime mapping process is done based on the police recorded reports from the victims hotspot areas are obtained. The maps of the crime hotspot that are accurately identified and clearly visualized will definitely give advantages to the police organization by guiding visualization of threat, allocation of police resource and prediction of the crime activities in the area (Chainey, Tompson, \& Uhlig, 2008). Simple maps that display the locations where crimes or concentrations of crimes have occurred can be used to help direct patrols to places they are most needed (Johnson, 2000). In the conventional hotspot research, the 400-metre radius would be referred to as the bandwidth of the model. The vital conceptual difference between the technique developed and the hot-spotting is that the bandwidth is relatively inconsistence for hot-spotting, or is selected on the basis of the statistical properties of the distribution of the data, whereas this specific distance of 400 meters is use as the distance which show the risk of burglary is communicable (Bowers, Johnson, \& Pease, 2004). Routine activity theory aids to clarify why crime frequently happen and concentrate at particular spaces. The concentrations of individual events that might indicate a series of related crimes are looked by the crime analysts which is similar to what the researchers would do. Small areas, neighborhoods and neighborhood clusters that have a great deal of high crime and disorder levels, even though there may be no common offender are observed and try to link these based on the social conditions.

With the latest developments in crime mapping, one can find a various size of hot spots, from a hot spot places to hot spots regions. The most important thing is the factors that led to the raise of the hot spot places are different from the factors that lead to the hot spot streets, hot spot neighborhoods, or hot spot cities. In addition, the actions of a person who is required to deal with the hot spot place will be different from the actions needed to address a hot spot street, hot spot neighborhood, or hot spot city. Therefore, to understand the theories basis for the crime hot spots is critical. Crime hotspot map that are accurately identified and clearly visualized definitely will give benefits to the police organization by guiding visualization of threat, allocation of police resource and prediction of crime (Chainey, Tompson, \& Uhlig, 2008). Techniques for detecting crime hotspots have been developed for several years, although there are no means at the stage where they are both definitive and applicable (Ratcliffe, 2004).

\subsubsection{Snatch theft}

'Snatch thefts' are part of the offence 'theft from the person' and are covered under the Theft Act 1968. The term target to bring to mind the image of an offender snatching a property away from the victim that is currently in his or her personal possession. Generally, the definition of snatch theft is a criminal acts of stealing property of other people by engaging rob-and-run tactics (Yew, 2012). Most of the incidents are ordinary to be operated by the offenders who is riding on a motorcycle which makes them easier to escape and save more time without their face being recognized by the surrounding people after committing the crime. Snatch thefts will either work alone or with a pillion rider, who is the one who usually do snatch action of items from pedestrians or other people either on motorcycles nor cars, while the motorcyclist rider tries to run away after obtaining their desired things. But there is also another method used by the snatch thieves which is called the smash-and-snatch tactic (Yew, 2012). This tactic is involved both motorcyclist and a pillion rider where the pillion rider will smash one of the car windows in order to snatch away the handbags or laptops that is located at any of the passenger seats in the car. This tactic occurs in a second without any verbal communication occurs between the offenders and the victims before the robbery (Monk, Heinonen, \& Eck, 2010). The most usual purse snatching incidents is that there will be two thieves riding a motorcycle, speed up towards a victim from behind where the passenger on the back snatches valuable items such as purse, handbag, or cellular phone. Thieves have also conducted snatch thefts while leaning out of the passenger side of moving vehicles (OSAC, 2015).

From the previous study, it was revealed that snatch thefts often occurred on a person's way home from work and the public facilities with high visibility are found to be relatively high at snatch theft incidents (Takizawa et al. 2010). There are some study related with snatch incidents have been conducted. One of the studies is there was a field survey that was done at suburban residential area which took place in Soka city of Saitama prefecture in Japan (Fujii, Sasaki, \& Kishimoto, 2013). The goal of the research study is to construct the estimation model about the damage risk using base data of urban space, road data, or Space Syntax, and the factor which contributes to a damage risk is clarified. Both of the scholars touched on the CPTED principles of surveillance provides by the public by using a certain radius from a transit station to identify the area where snatching incidents take place.

\subsubsection{Street design}

Street acts and is known as the 'skeleton' of an urban area, in the sense that it is the structure over which elements of the built environment are organized in today's modern days. In the urban form, street is an important component and all the city dwellers are utilizing it in the most city spaces (Abdul Rahman \& Md Sakip, 2015) but there are still many streets that remain unsafe for the people in urban neighborhoods (Riggs \& Gilderbloom, 2017). The distinctive parts of the neighborhoods is connected with streets and also the private and the public realm are associated with it. These linkages supported the social interaction and exchange, where both are having crucial functions. Street design contributes significantly to the quality and characteristics of the community (Grammenos \& TaskerBrown, 2001). It is also in order to include promoting an accessible and safe quality of the urban environment (Abdul Rahman \& Md Sakip, 2015). There are several types of street pattern which are conventional suburban loops and cul-de-sacs, and traditional grid 
models. The use of grids were directly accessible from all parts of the suburb. Street and crime has a relation that existed for a very long time. Residents living in highly accessible street layouts are statistically more likely to have a high regards fear of crime and low social unity and it was also found that crimes often take place in these highly accessible places (Hedayati Marzbali, Abdullah, Razak, \& Maghsoodi Tilaki, 2012; An \& Yoshida, 2013). The changes in shape and connectivity of the street patterns are being emphasized in Stephen Marshall's sketch and M. Southworth shown below which is going from fully-connected networks to increasingly more dendritic networks. If the street pattern of both scholars were to compare, Marshall stated the evolution started from 1920s until 1950 while Southworth started from 1900s to 1980s. Although there is a slight distinctive in the time frame of the street patterns transformation, it still can be concluded that both of their findings are having similar patterns which is from higher to lower access of the streets. Actually is just not about the changes in connectivity and shape of the streets but also the density which is with increasingly less dense network over the last half of the late 20th century. These diverse changes are usually diverse by many observers of this evolution in the street network (Marshall \& Garrick, 2010).

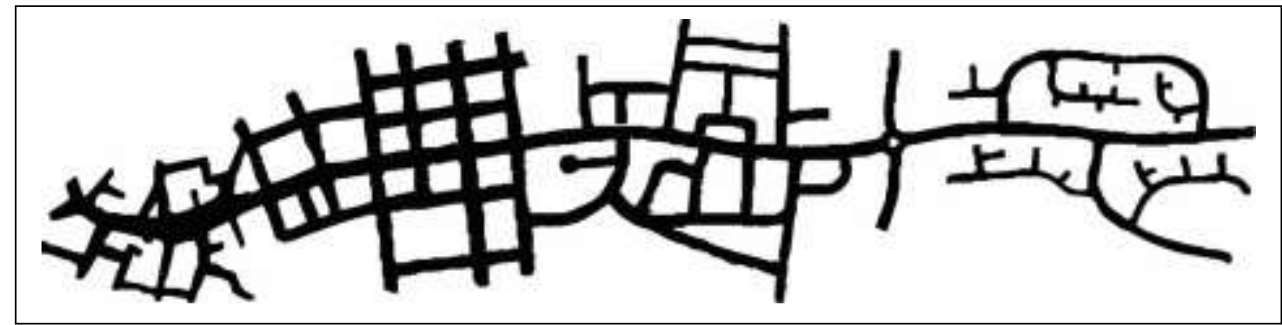

Fig. 1: Evolution of street pattern from 1920s to 1950s

(Source: Marshall, 2005)

\begin{tabular}{|l|l|l|l|l|l|}
\hline $\begin{array}{l}\text { Gridiron } \\
\text { (c. 1900) }\end{array}$ & $\begin{array}{l}\text { Fragmented } \\
\text { parallel } \\
\text { (c. 1950) }\end{array}$ & $\begin{array}{l}\text { Warped } \\
\text { parallel } \\
\text { (c. 1960) }\end{array}$ & $\begin{array}{l}\text { Loops and } \\
\text { lollipops } \\
\text { (c. 1970) }\end{array}$ & $\begin{array}{l}\text { Lollipops } \\
\text { on a stick } \\
\text { (c. 1980) }\end{array}$ \\
\hline $\begin{array}{l}\text { Street } \\
\text { patterns }\end{array}$ & &
\end{tabular}

Fig. 2. Evolution of street patterns from 1900 s to 1980 s

(Sourde: Southworth, 1997)

The previous scholars have classified the street patterns into five typical categories as shown in Fig. 2. The patterns were gridiron, fragmented parallel, warped Parallel, loops and Lollipops and lollipops on a stick (Southworth, 2003). The gridiron street layout is a traditional pattern which exists in most of early urban planning for example in Europe countries. The advantages of this pattern is that it helps a compact settlement in order to use the spaces efficiently because mainly the gridiron pattern consists of linear roads. Gridiron street pattern reappear in some settlements, which are easily associated with each other. This kind of street is having a feature of being easy to survey, have very clear directions which able to make shortcuts from one place to another. Gridiron pattern is very popular among most of the road engineers and the planners is obviously because of its simplicity (Li, 2011). While as for its disadvantages, nowadays, most of the cities have been taking the street hierarchy, curvilinear design, and disconnected networks into consideration (Wolfe, 1987). From the snatch incident aspects, gridiron provide the most accessibilities as compared from the other four street patterns which can provide numbers of easy entries and high numbers of escape routes for the offenders. Since the snatch theft offenders are likely to ride a motorcycle, it will be very easy for them to escape by doing different turnings at every single road segments within the gridiron layout. Jacobs (1961) observed that the streets with the high level of activities and people existence, the crime activities are lower (Zaki \& Abdullah, 2012). The design of these roads as observed by Jacobs are more conventional and in grid layout, where people who pass by acts as a casual surveillance (Zaki \& Abdullah, 2012).

The second type of street pattern is the fragmented parallel pattern which has most street segment into $\mathrm{T}$ intersections and L-shaped corners. The number of access points for this pattern, the preferred routes through a neighborhood and the interconnection of street are reduced. Although, this pattern has almost the same street length as the gridiron, it has limitation in the number of traffic flow (Southworth, 1993). The next street pattern is the warped parallel pattern. This pattern has similarities with the fragmented parallel pattern in the shape of a space. Its characteristics consist of long and narrow blocks, hardly consists of any preferred route, crossroad intersections and interconnection are limited, but it is having a curvilinear rather than straight road or street. Curved road usually creates the impression of rural area and the visual length is shortened and the topography is used to generate this pattern (Li, 2011). The orientation of the users in the block is confused by the curvilinear street (Southworth, 1993). As a whole, compared with fragmented parallel, it is not an auto-friendly block with the warped parallel pattern ( $\mathrm{Li}, 2011)$. The fourth type of the street pattern is the loops and lollipops pattern. The street design is an evolution from the warped parallel to loops and lollipops pattern since 1970 (King, 2005). This street pattern consists of numbers of loops and cul-de-sacs within the layout which makes the direction of the street is multiple. The limitation 
of the connectivity gives a sense of privacy and calmness (Li, 2011). The limited accessibility is an even more severe problem than the other non-loops patterns. Thus, both vehicles and pedestrians are having less interest to cross or use the paths through communities with this pattern (Southworth, 1993). Last but not least, the final pattern is the lollipops on a stick street pattern. This pattern also named or known as cul-de-sacs or streets with dead-ends. It has the least linkages, preferred routes and accessibilities (Southworth, 1993). When other forms of street pattern such as cul-de-sacs and loops were introduced, residential layouts appear to have lesser continuous, linear and through streets (Zaki \& Abdullah, 2012). Therefore, an appropriate tool to analyze the context of a more general built environment is provided. It has a certain significance in the criminal case in which the target is an element of the built environment, and therefore is at a fixed point on the network such as burglary, that will be considered here.

Street networks dominate the movement patterns, awareness space and criminals target choices, especially those who are using vehicles or street-level public transportation (Beavon, Brantingham, \& Brantingham, 1994). This indirectly shows that the formation of the built environment affects the individual activities (Davies \& Johnson, 2015). The relationship between the urban form and crime always related with the linkage of street pattern. The street linkage defines as a path moving from any two or more locations which is the basic element for pedestrians and vehicular movement in an urban area. We assumed that street connections would contribute to snatching occurrences because most snatches occurred on streets (Fujii, Sasaki, \& Kishimoto, 2013). The framework emphasizes that crime and fear of crime may have substantial impacts on wellbeing, but the pathways are often highly indirect, mediated by environmental factors, difficult to disentangle and not always in the expected direction (Lorenc et al., 2012). There are two slight different views on the relationship between street layouts and fear of crime that pinpointed in the existing literature overview (Hedayati Marzbali et al., 2012). The street sidewalk usage which brings in more strangers is a basic feature of a safe city (Jacobs, 1961) while the other one is the defensible space concept suggested that the higher perceived use and density of people on city streets are associated with the greater levels of fear (Newman, 1972). Newman also insisted in restricting access, minimizing interconnectedness and a clear demarcation between public and private spaces. It should be noted however that the context in both of Jacobs and Newman's studies operate may be the influencing factor. Jacobs (1961) drew attention to the urban design and narrowed the investigation area of crime-space studies. Her study is more concerned with macro-scale planning such as commercial and business settings, while Newman's work focused on microscale settings such as public housing and residential settings (Hedayati Marzbali et al., 2012).

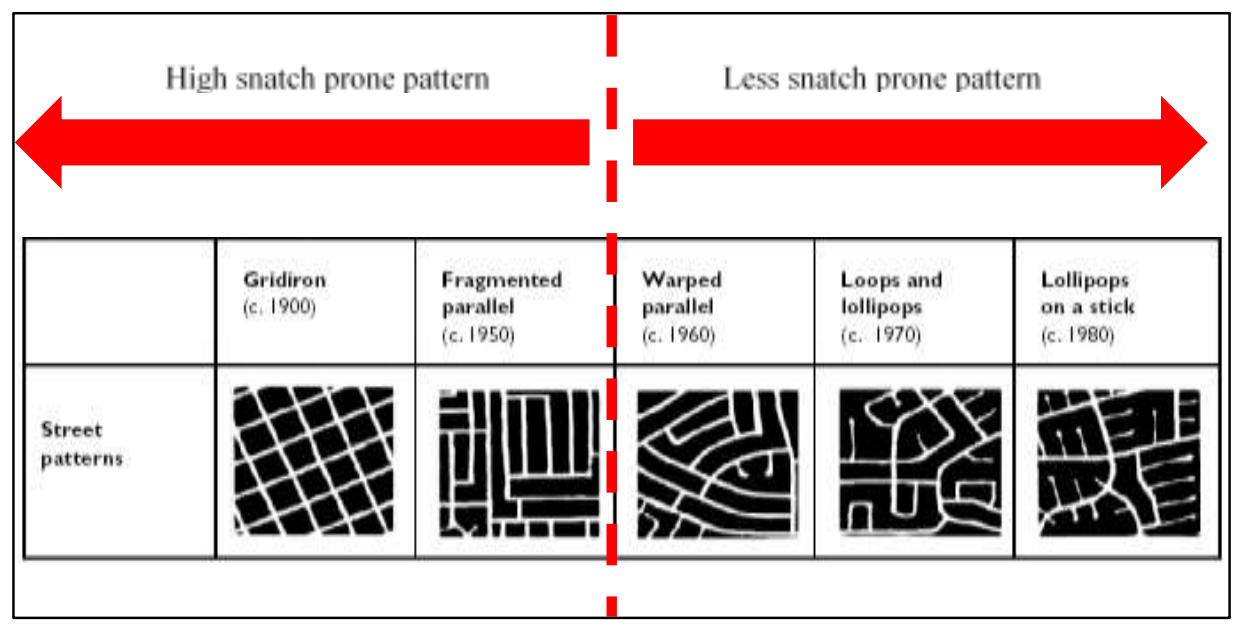

Fig. 3. Snatch prone street pattern

(Source: adapted from Southworth (1997)

According to Fig. 3 which has been adopted from Southworth (1997), the table is divided into two parts. The first part with the arrow on the left is a high snatch prone street pattern while on the right side arrow is less snatch prone street pattern. In the earlier ones, the layout has higher permeability and movement is encouraged; while in the recent layout, the permeability is less or impermeable, and the movement is restricted. The first two street pattern on the left, which are the gridiron and the fragmented parallel, has higher number of accessibilities compared to the other three types of the street pattern which are having less access or entry. As mentioned earlier, the gridiron is more accessible and navigable from any direction in a city. To relate it with snatch theft incidents, gridiron provides a lot of entry and escape routes rather than warped parallel, loops and lollipops, and lollipops on a stick street patterns. Previous study that was done by Hillier and Shu (2000) who was using space syntax, they not only presented that the environment such as spaces in the residential areas affect the crime but they also indicate the characteristics in the urban layouts that influenced the unequal distribution of burglary (Zaki \& Abdullah, 2012). In realization of this study, it is very hard to find previous research or study that have been done by previous scholars regarding street pattern and snatch theft incidents. Therefore, this is a new study of a specific street crime which is snatch theft with the street pattern. From the GIS results, it shows that street pattern with high permeability or accessibility is associated with snatch theft incidents. 


\subsection{Methodology}

This research is qualitative approach. The data will first be obtained from Polis Diraja Malaysia (PDRM) since this study is involved with the crime statistics. Snatch theft statistical data that has been obtained from PDRM will be sorted out according to the states as shown in Table 1, districts shown in Table 2 and the road or street names from the highest to the lowest number of recorded cases. Table 1 shows the four main cities in Malaysia which are Selangor, Kuala Lumpur, Penang and Johor. The state in bold font shows the state with high numbers of recorded snatch theft cases from the statistical data from PDRM. While for Table 2, it shows the 14 districts exist in Selangor which the scope has been narrowed down in order to choose a case study location and Ampang Jaya has been chosen as the case study location based on the high number of recorded snatch theft incidents. This study will be focusing on the street with high number of reported cases of snatch incidents to identify what kind of street pattern and physical environment that contribute to the hotspot area of the snatches. The Geographic Information System (GIS) is used for this study in order to produce hotspot map based on the snatch theft statistical data from PDRM. Snatch theft hotspot map is produced after the police data is inserted into the map of Ampang Jaya by using ArcMap 10.2. The areas in Ampang Jaya is divided according to the existing districts. After the data has been inserted and snatch theft incidents are located, these areas categorised into five different colour coded which are red, orange, yellow, light green and green in order to identify which area will be the hotspot area. Red colour represent an area with the highest number of snatch theft cases while green with the lowest or no snatch theft cases.

Table 2. Snatch Theft Crime Data in 14 districts in Selangor from 2010 to 2015 (PDRM, 2016)

\begin{tabular}{l|l|l|l|l|l|l|l}
\hline District & 2010 & 2011 & 2012 & 2013 & 2014 & 2015 & $\begin{array}{l}\text { Total } \\
\text { District }\end{array}$ \\
\hline Ampang Jaya & 429 & 260 & 321 & 322 & 257 & 220 & 1809 \\
\hline Gombak & 67 & 8 & 5 & 5 & 1 & 3 & 89 \\
\hline Ulu Selangor & 6 & 1 & 2 & 5 & 3 & 10 & 27 \\
\hline Kajang & 16 & 1 & 79 & 127 & 150 & 128 & 501 \\
\hline Klang Selatan & 114 & 90 & 13 & 82 & 31 & 21 & 369 \\
\hline Klang Utara & 14 & 31 & 13 & 31 & 17 & 14 & 120 \\
\hline Kuala Langat & 25 & 12 & 4 & 6 & 9 & 8 & 64 \\
\hline Kuala Selangor & 23 & 14 & 2 & 1 & 2 & 4 & 46 \\
\hline Petaling Jaya & 135 & 79 & 82 & 183 & 153 & 355 & 987 \\
\hline Sabak Bernam & 42 & 19 & 17 & 15 & 21 & 27 & 141 \\
\hline Sepang & 13 & 7 & 6 & 4 & 11 & 8 & 49 \\
\hline Serdang & 66 & 82 & 30 & 50 & 22 & 41 & 291 \\
\hline Shah Alam & 102 & 43 & 7 & 6 & 3 & 2 & 163 \\
\hline Subang Jaya & 195 & 152 & 127 & 130 & 151 & 70 & 825 \\
\hline Sungai Buloh & - & - & - & 18 & 15 & 39 & 72 \\
\hline
\end{tabular}

(Source: PDRM, 2016)

\subsection{Result and Findings}

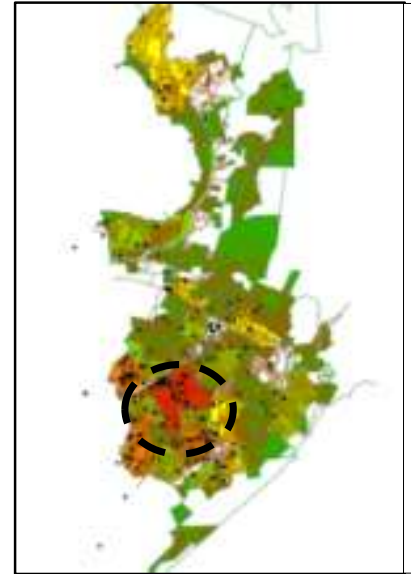

(a) Snatch theft cases in 2010

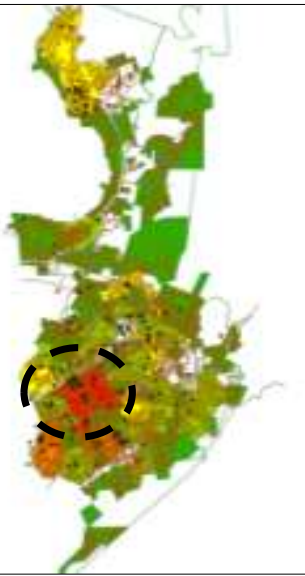

(b) Snatch theft cases in 2011

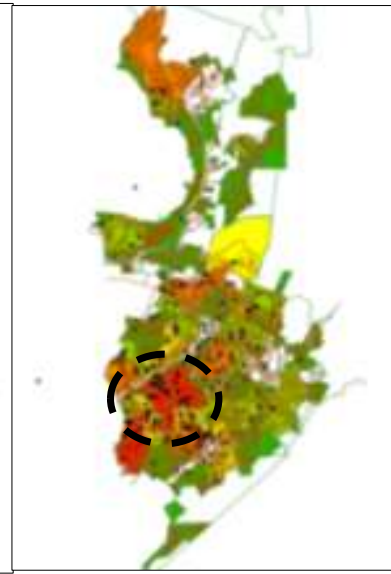

(c) Snatch theft cases in 2012 


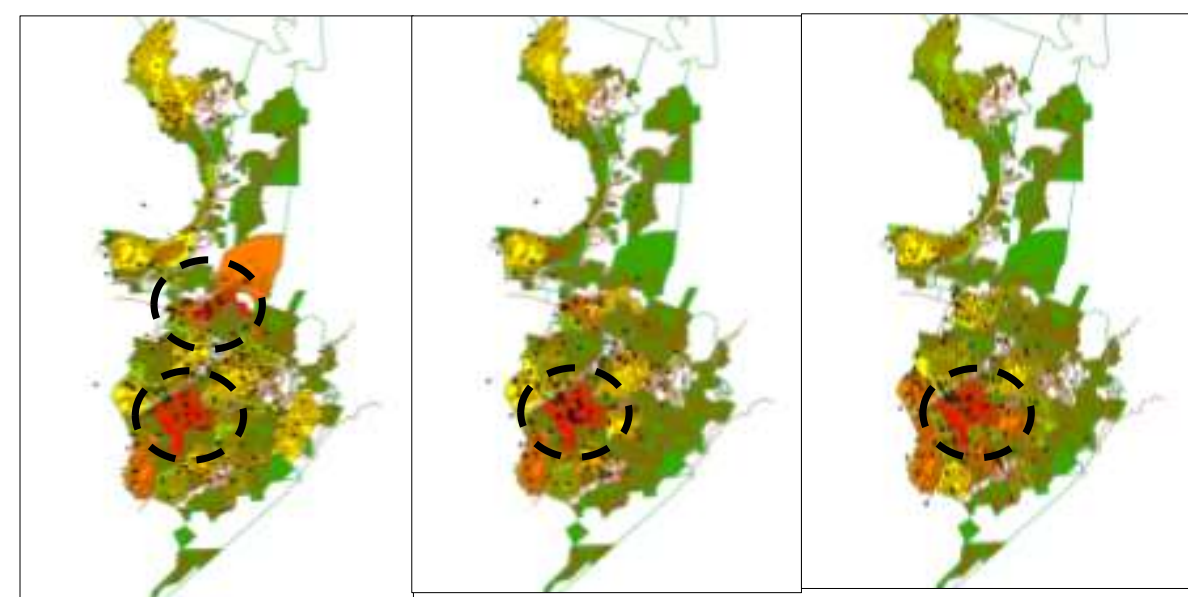

(d) Snatch theft cases in 2013

(e) Snatch theft cases in 2014

(f) Snatch theft cases in 2015 Note: $\mathcal{H}$ Hotspot area

Fig. 4(a-f) Snatch theft cases in Ampang Jaya from 2010 until 2015

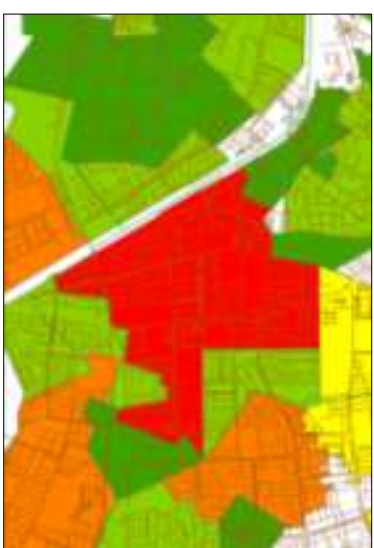

Fig. 5 Hotspot area in red color is Pandan Indah

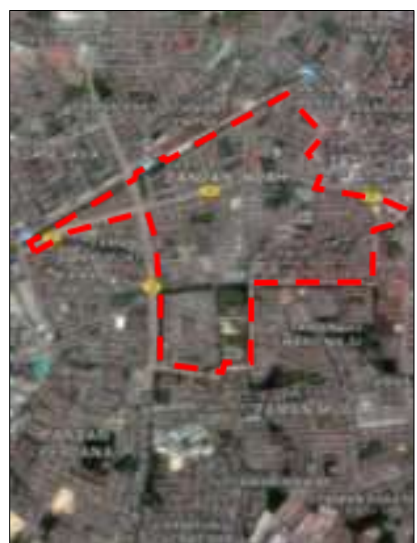

Fig. 6 Satellite view of Pandan Indah

Note: Pandan Indah boundary

Source:"̛oogle Map, 2017)

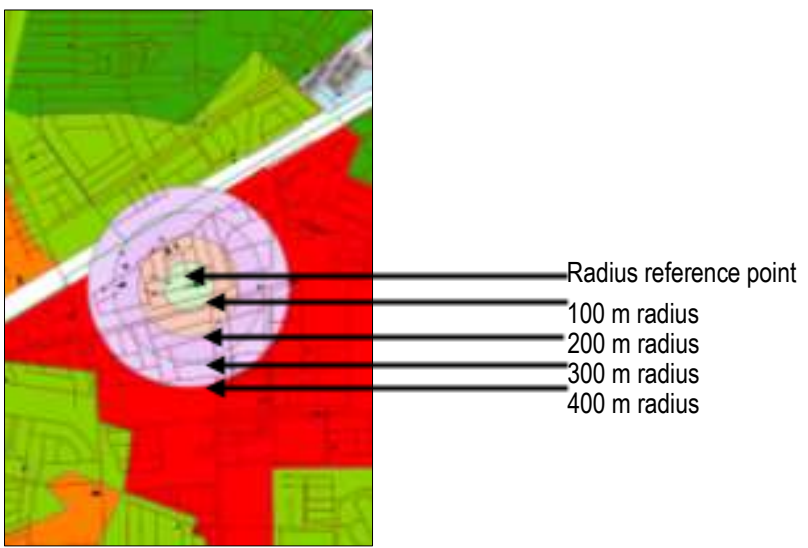

Fig. 7 A 400 meter radius is used from the street with high snatch theft cases

The Image 4(a-f) which the results of the hotspot map obtained using ArcMap 10.2 from the year of 2010 until 2015 respectively. The dotted lines represent the number of cases occurred in the particular areas according to the statistical data from Royal Malaysian Police (RMP). These six maps shows the pattern of the distribution of the snatch theft incidents in Ampang Jaya district. It can be seen that the snatch theft activities tend to take place on the southwest of Ampang Jaya. Based on the maps in Image 4(c), Ampang Jaya was having high cases of snatch theft where there are color changes from the previous year in Image 4(a-b). But in Image 4(d-f), it seems there is some places were having a decrease in number of snatch theft incidents 
especially in the northern part of Ampang Jaya. From the Image 4(a-f), the hotspot area is shown in red color which is located in Pandan Indah, Ampang. In these 6 years period of time, it seems as if there is no reduction of snatch theft incidents in Pand an Indah. Therefore, Pandan Indah shown in red color in Fig. 5, is selected as the case study area for this research which is located within the Ampang Jaya local authority area. This area especially consists of two types of major land uses which are the commercial areas and the residential areas.

The hot spot area in Pandan Indah is focused towards the most incidents happened in the area. There are high number of snatch theft cases in the neighborhood area on the Northwest of Pandan Indah in the year of 2015 in Fig. 4. In Figure 7, a 400 meter radius is used with a reference point at Jalan Pandan Indah 12 due to its high number of snatch theft cases in the most recent years that is in 2015. This specific distance of 400 meters is use as the distance to show the risk of burglary is communicable (Bowers, Johnson, \& Pease, 2004) to be committed by the offenders. The street pattern of the residential is examined at this level. This is done by comparing the street pattern of the residential area from the previous studies of the street patterns. If it were to compare the examples of the street patterns mentioned in the literature with the case study area, this area is having a fragmented parallel street pattern. Fragmented parallel pattern is having almost as high accessibility as compared to the gridiron pattern network even though the pattern might seems to have less direct access or less navigable pattern. From the google map, this residential area is located between Pandan Indah main road and Light Rapid Transit (LRT) rail station. Thus, this neighborhood can be access by anyone especially to those who want to use the LRT facility. People are going in and out from the neighborhood to enter and exit the main road at any time of the day. Residents in this neighborhood too will use the same routes as others. So, nobody can never know whether a person is from this neighborhood or an outsider. Sight distance, street width, the number of escape routes (Fujii, Sasaki, \& Kishimoto, 2013), household density, population density, and the presence of financial institutions, transport hubs, police station and open space (Kinashi \& Kin, 2008) are several factors influencing snatches activities. It can be concluded that the factors of snatch theft incident to happen in this reside ntial area is because there is the presence of the number of escape routes, street width, transport hub, and open space.

Fig. 5 and Fig. 6 is to compare the digitized map from GIS and satellite map from Google Map where is the highest snatch incident took place. From Google map in Fig. 6, the neighborhood road have direct access towards the Pandan Indah main road. A motorcycle is often used by the snatch theft because it is smaller than a car and easier for them to commit the crime. Due to this reason, it is easier for them to escape especially by using the smaller routes that cannot be access by bigger vehicles such as cars. In this neighborhood, closed routes and dead-ends are also exists due to the shape or the street pattern which has L-shaped corners. Some of the routes might be not accessible for cars and lorries. This might be because of the street pattern is straight; not difficult to analyze and have a clear ways which are able for the offenders to find shortcuts from one place to another. This street also has a direct access to the main road which will be an advantage for the snatch offenders to escape. Linear or straight road is easier to predict what is up ahead rather than winding roads. This straight road give a clear vision and direction for the offenders to choose which way to escape if there is any intersections in front of them. Motorcycles are smaller in size and can use any paths or passage available for it to get through. Even though there are witnesses during the incidents happened, they are not able to help by going after the offenders especially by using cars since the offenders will definitely find and use any escape routes available regardless of its size

\subsection{Conclusions}

Snatch theft is becoming a critical issues in Malaysia especially in the cities. Snatch theft incidents has been causing deaths and injuries as reported in the daily local newspaper, articles and videos that are being uploaded on the internet by witnesses. One of the reasons for this incident to happen is due to the awareness level of people in snatch theft issues are very low and it can cause the victims to be traumatized for a very long time especially the women. While from the results obtained, it can be seen that the snatch theft incidents happened in the residential area in Pandan Indah. Usually snatch theft incidents tend to happen in the urban area such as commercial and public areas rather than the residential areas. This might be because of the street design in the neighborhood which has easy access and escape routes for the snatch offenders. Most of the streets in Pandan Indah are straight or linear street that is connected directly with the main road, Jalan Pandan Indah, which can be accessed by anyone at any time. Even though this area is a residential area, the residents in the neighborhood do not tend to be outside of the house all the time as compared to the commercial area or public spaces which can provide informal surveillance by the public. This might be one of the advantages for the snatch theft to commit the crime within the neighborhood.

If it were to relate with Newman's (1972) and Jacobs' (1961) theories with the study of the snatch theft hotspot study, the results from the study shows that the snatch theft incidents happened in residential area where the area is clearly has its own territory and based on the street pattern layout, the study area has as high accessibilities as grid iron street pattern layout. As we are aware, Jacobs is focusing on commercial areas which located within grid layout because these areas provide higher level of surveillance and has higher access by the public while Newman is focusing more on residential areas which provide a clear territoriality boundaries in a less accessible layout. Based on this, the area is having its own territory which is also having high surveillance from the public coming to and fro the area. Although, the study area has similar features as describe by Newman and Jacobs, the area still end up with high snatch theft incidents happened and became a hotspot area.

Besides that, this neighborhood also is connected with the transit hub, LRT Pandan Indah, where people are walking, cycling or driving to use the facility provided. It is noted that the victims of the snatch incidents are often to be the pedestrians who are walking. The victims here might be the people who are walking to the LRT station going to work or coming back home from work. Within this neighborhood, if the street design layout to be observed, it was found that the area is having a confusing street layout 
where there is an access below the elevated main road from the other neighborhood to this neighborhood. Generally looking at Fig. 5, we can never see or know there is an access from the opposite neighborhood to this neighborhood. It seems as if the offenders who are the snatch thefts for this study, might be someone that already knows the layout of the neighborhood area and the potential victims within it. The environmental criminologists have linked the pattern of crime to the environmental and physical layout of the places where the crime take place (Abdullah, Razak, Salleh, \& Sakip, 2012). Snatch theft activities usually happen before dawn and in the late evening and happens frequently around pathway near to the roadside, transit areas, and area with less or no people. Other than that, snatch theft often occurs and find the target victims when they are on the way to go home. Street design plays a crucial roles especially in an urban area since streets connect one place to another place.

Local authorities, architects, landscape architects and town planners are still gathering ideas and energy to produce a comfortable, convenient, healthy and safe city for the citizens. The local organization also are putting great efforts to apply Crime Prevention through Environmental Design (CPTED) in order to reduce the number of the crime rates nationally. Overall, it can be seen that the elements of physical environment that is the street pattern in an area can be one of the facto rs in contributing the crimes to happen within a space or area. This matter are able to cause uneasiness to the community since the setting of the environment is an vital elements as factors of feeling of security (Sakip, Rahman, \& Nayan, 2016) and it is important to produce good street design and safer surrounding in order to prevent abundant access into the neighborhood where it can provide easy access and escape routes for the offenders to commit the crimes. Planners, architects, engineers and other related fields should do a thorough study when designing and producing a new place or urban area so that the crime can be reduce especially from the physical environmental aspect such as the street pattern layout, the location of the buildings, entrance and exits of a place to produce a safe, livable, and sustainable cities. This is an important matters that needs to be evaluate in the future research of this study.

\section{Acknowledgements}

In realizing this study, the researchers would like to thank the Royal Malaysian Police (PDRM), Ministry of Higher Education by the Malaysian Government to support this research by the Research Acculturation Collaborative Effort (RACE) of (600RMI/RACE16/6/2(3/2015)).

\section{References}

Abdul Rahman, N., \& Md Sakip, S. R. (2015). Relationship between accessibility and safety criterias with the uses of the street: A case study of urban commercial street in Kuala Lumpur city centre. Advances in Environmental Biology, 47-50.

Abdullah, A., Razak, N. A., Salleh, M. N. M., \& Sakip, S. R. M. (2012). Validating Crime Prevention through Environmental Design Using Structural Equation Model. Procedia - Social and Behavioral Sciences, 36, 591-601.

An, J., \& Yoshida, T. (2013). Use of Omnidirectional Images to Analyze Elderly People's Feelings of Insecurity about Snatch Occurrences on Roads. Journal of Asian Architecture and Building Engineering, 12(2), 301-308.

Anderson, J. M., Macdonald, J. M., Bluthenthal, R., \& Ashwood, J. S. (2013). Reducing Crime by Shaping the Built Environment with Zoning: An Empirical Study of Los Angeles, Vol. 161:(699), 699-756. Retrieved from http://scholarship.law.upenn.edu/cgi/viewcontent.cgi?article=1016\&context=penn_law_review

Beavon, D. J. K., Brantingham, P. L., \& Brantingham, P. J. (1994). The influence of street networks on the patterning of property offenses. Crime Prevention Studies, Vol 2 , 115-148. Retrieved from http://www.popcenter.org/library/crimeprevention/volume_02/06beavon.pdf

Block, R. L. \&, \& Block, C. R. (1995). Space, Place And Crime: Hot Spot Areas And Hot Places Of Liquor-Related Crime. Crime and Place.

Brantingham, P., \& Brantingham, P. (1984). Patterns in Crime. National Criminal Juctice. Retrieved from https://www.ncjrs.gov/App/Publications/abstract.aspx?ID=110611

Brantingham, P. L., \& Brantingham, P. J. (1993). Nodes, paths and edges: Considerations on the complexity of crime and the physical environment. Journal of Environmental Psychology, 13(1), 3-28. http://doi.org/10.1016/S0272-4944(05)80212-9

Chainey, S., Tompson, L., \& Uhlig, S. (2008). The Utility of Hotspot Mapping for Predicting Spatial Patterns of Crime. Security Journal. http://doi.org/10.1057/sj.2008.6 Chowdhury, U. (2014). Street Crime and Physical Environment - From the Perception of Local People regarding Security Feelings, 3(1), 66-81.

Clontz, K. A. (1997). Spatial analysis of residential Burglaries in Tallahassee, Florida. annual environmental systems research institute (ESRI).

Colquhoun, I. (2004). Design Out Crime: Creating Safe and Sustainable Communities. Crime Prevention and Community Safety.

Cozens, P. (2008). Crime prevention through environmental design in Western Australia: Planning for sustainable urban futures. International Journal of Sustainable Development and Planning, 3(3), 272-292

Eck, J. E. (1998). Preventing Crime by Controlling Drug Dealing on Private Rental Property. Security Journal, 11(1), 37-43.

Faizah, M. L. (2015). Ke arah pengurangan indeks jenayah jalanan di Pusat Bandar Kuala Lumpur Towards reducing the street crime index of Kuala Lumpur City Centre, 4(4), $97-107$. 
Fujii, T., Sasaki, Y., \& Kishimoto, T. (2013). Estimation Of The Risk Of Snatching In A Suburb: Case study of Soka, Saitama prefecture, Japan. Proceedings of the 9th International Space Syntax Symposium, Seoul, 111:1-111:10.

Greenberg, S. W., \& Rohe, W. M. (1984). Neighborhood design and crime: A test of two perspectives.

Gonzales, A. R., Schofield, R. B., \& Hart, S. V. (2005). Mapping Crime: Understanding Hot Spots. National Institute of Justice, 79. Retrieved from http://discovery.ucl.ac.uk/11291/1/11291.pdf\%5Cnhttp://discovery.ucl.ac.u/11291/

Grammenos, F., \& Tasker-Brown, J. (2001). Residential Street Pattern Design, 1-11.

Haberman, C. P., \& Ratcliffe, J. H. (2015). Testing for Temporally Differentiated Relationships Among Potentially Criminogenic Places and Census Block Street Robbery Counts. Criminology, 53(3), 457-483.

Howsen, R. M., \& Jarrell, S. B. (1987). Some Determinants of Property Crime: Economic Factors Influence Criminal Behavior but Cannot Completely Explain the Syndrome. American Journal of Economics and Sociology, 46(4), 445-457. Retrieved from http://www.jstor.org/stable/3486660

Jabatan Penerangan Malaysia. (2009). Enam Bidang Keberhasilan Utama Negara Nkra . Retrieved June 16, 2016, from http://pmr.penerangan.gov.my/index.php/nkra/4808pointers-6-bidang-keberhasilan-utama-negara-nkra.html

Kinashi, M., \& Kin, T. (2008). Study of the Crime Space Based on Analyzing Criminogenic Factors for Crime Prevention. Infrastructure Planning Review, 25(1), 329-338. http://doi.org/10.2208/journalip.25.329

Kuo, F. E., \& Sullivan, W. C. (2001). Environment and crime in the inner city: Does vegetation reduce crime? Environ. Behav., $33(3), 343$.

Lakshiny. (2016). 7 To 8 Police Reports Daily On Snatch Thefts In KL, Malaysians Need To Look Out For Each Other To Overcome This Crime. Retrieved July 27, 2016, from http://malaysiandigest.com/

Li, D. X. (2011). Effects Of Street Pattern On Frequency Of Traffic Crash: A Case Study Of Gainesville, Florida. University Of Florida.

Liggett, R., Loukaitou-sideris, A., Iseki, H., \& Candidate, D. (2003). Protecting Against Transit Crime :, 139-156.

M.P., P. (2004). Factors of the Physical Environment Associated with Walking and Bicycling. Medicine and Science in Sports and Exercise, 36(4), 725-730.

Maltz, M. D., Gordon, A. C., \& Freidman, W. (1991). Mapping crime in its community setting: Event geography analysis. Mapping crime in its community setting: Event geography analysis.

Mazeika, D. M., \& Kumar, S. (2016). Do Crime Hot Spots Exist in Developing Countries? Evidence from India Research Note. Journal of Quantitative Criminology, 1-17.

Monk, K., Heinonen, J. A., \& Eck, J. E. (2010). Street Robbery The Problem of Street Robbery What This Guide Does and Does Not Cover. Retrieved from http://www.popcenter.org/problems/street_robbery/print/

Nagaie, T., Hokao, K., \& Inohae, T. (2007). Analysis of Surveillance and Territoriality on CPTED and relation for the fear of crime-Based on Axial line and Isovist on Space syntax theory-. Journal of the City Planning Institute of Japan, 42(3), 505-510.

Nasar, J. L., \& Fisher, B. (1993). "Hot spots" of fear and crime: A multi-method investigation. Journal of Environmental Psychology, 13(3), 187-206.

Nubani, L., \& Wineman, J. (2005). The Role of Space Syntax in Identifying the Relationship Between Space and Crime. Proceedings 5th International Space Syntax Symposium, $413-422$.

Ortega, F. B., Ruiz, J. R., \& Sjostrom, M. (2007). Physical activity, overweight and central adiposity in Swedish children and adolescents: the European Youth Heart Study. International Journal of Behavioral Nutrition and Physical Activity, 4, 61-71.

OSAC. (2015). Malaysia 2015 Crime and Safety Report, 1-8. Retrieved from https://www.osac.gov/pages/ContentReportPDF.aspx?cid=17215

PDRM, P. D. R. M. Statistik Jenayah Ragut (2016)

PDRM, P. D. R. M. Statistik Jenayah Ragut (2016)

Perkins, D. D., Wandersman, A., Rich, R. C., \& Taylor, R. B. (1993). The Physical Environment Of Street Crime: Defensible Space, Territoriality And Incivilities, 29-49.

Ratcliffe, J. H. (2004). The Hotspot Matrix: A Framework for the Spatio-Temporal Targeting of Crime Reduction. Police Practice and Research, 5(1), 5-23.

Riggs, W., \& Gilderbloom, J. I. H. (2017). How multi-lane, one-way street design shapes neighbourhood life: collisions, crime and community. Local Environment, 1-17.

Roncek, D. W., \& Maier, P. A. (1991). Bars, Blocks, And Crimes Revisited: Linking The Theory Of Routine Activities To The Empiricism Of "Hot Spots" Criminology, 29(4), 725-753.

Sakip, S. R. M., Rahman, N. A., \& Nayan, N. M. (2016). Do they Feel Fear without Fence? Procedia - Social and Behavioral Sciences, 222, 738-746.

Spicer, V., Song, J., Brantingham, P., Park, A., \& Andresen, M. A. (2016). Street Profile Analysis : A New Method For Mapping Crime On Major Roadways. Applied Geography, $69,65-74$

Tadashi, N., Kazunori, H., \& Takuro, I. (2008). Analysis of the relationships between the accessibility of urban space based on the Space Syntax Theory and the opportunity crime, the police' s perceived risk of crime. Journal of the City Planning Institution of Japan, (43-3), 769-774 
Takizawa, A., Koo, W., \& Katoh, N. (2010). Discovering Distinctive Spatial Patterns of Snatch Theft in Kyoto City with CAEP. Journal of Asian Architecture and Building Engineering, 9(1), 103-110.

Taylor, R. B., \& Harrell, A. V. (1996). Physical Environment and Crime. Rockville. Retrieved from https://www.ncjrs.gov/pdffiles/physenv.pdf

The Star. (2016, April 28). Lee : Crime index down , but not public fear. Star Media Group Berhad, pp. 1-2.

Wang, D., Ding, W., Lo, H., Stepinski, T., Salazar, J., \& Morabito, M. (2013). Crime hotspot mapping using the crime related factors - A spatial data mining approach. Applied Intelligence, 39(4), 772-781.

Weisburd, D., Groff, E. R., \& Yang, S. M. (2013). The Criminology of Place: Street Segments and Our Understanding of the Crime Problem. The Criminology of Place: Street Segments and Our Understanding of the Crime Problem.

Weisburd, D., Morris, N. A., \& Groff, E. R. (2009). Hot spots of juvenile crime: A longitudinal study of arrest incidents at street segments in Seattle, Washington. Journal of Quantitative Criminology, 25(4), 443-467. http://doi.org/10.1007/s10940-009-9075-9

Weisel, D. L., Gouvis, C., \& Harrell, A. V. (1994). Addressing community decay and crime: alternative approaches and explanation, (202).

Wolfe, C. (1987). Streets regulating neighborhood form: A selective history. Public Streets for Public use. New York: Van Nostrand Reinhold.

Yew, E. L. (2012). Situation Analysis of Snatch Theft Issue in Malaysia. Multimedia University (MMU).

Zaki, S. A., \& Abdullah, J. (2012). The relationship between variations of grid layout and Burglary. Planning Malaysia, 10(June 2016), 17-40. 